\title{
Trochocarpa montana (Ericaceae), an endemic new species from the Northern Tablelands area of north-eastern New South Wales
}

\author{
John B. Williams ${ }^{\dagger 1}$ and John T. Hunter ${ }^{2}$ \\ ${ }^{1}$ Botany, Centre for Ecology, Evolution and Systematics, University of New England, Armidale \\ NSW 2351, Australia \\ ${ }^{2}$ School of Human \& Environmental Studies, University of New England, Armidale, NSW 2351
}

\begin{abstract}
Trochocarpa montana J.B.Williams \& J.T.Hunter, a restricted montane species from the Northern Tablelands area of New South Wales is described. Notes are provided on its distribution, ecology and conservation status.
\end{abstract}

\section{Introduction}

A mountain form of Trochocarpa laurina has been recognised, described informally and treated as a separate taxon in works such as Williams et al. (1984), Floyd (1989), Wiecek (1989) and more recently Harden et al. (2006). This putative taxon has also been included in molecular phylogenetic analyses of the tribe Styphelieae (Quinn et al. 2003). The senior author was preparing descriptions of a number of new taxa over recent years, but his untimely death prevented their completion. Publications of some of these have recently appeared (Hunter et al. 2006; Williams \& Hunter 2006) but others still await formal description. This paper presents the formal description of the distinct mountain form of Trochocarpa laurina from the Northern Tablelands region of New South Wales as a separate species.

Trochocarpa montana J.B.Williams \& J.T.Hunter, sp. nov.

T. laurinae similis sed foliis minoribus fimbriatis alternatis (haud pseudoverticillatis), fructu minore, caulibus, bracteis bracteolisque hirsutis differt.

Trochocarpa species, sensu Floyd (1989, p. 123); Harden et al. (2006, p. 142).

Trochocarpa sp. A., sensu Wiecek (1992, p. 434).

Illustrations: Floyd (1989, p. 123); Wiecek (1992, p. 434); Harden et al. (2006, p. 142).

Type: New South Wales: Northern Tablelands: c. 2 km NW of Round Mountain, Cathedral Rock NP (30²4'46"S 15113'02"E), J.T. Hunter 2579, J.J. Bruhl \& F.C. Quinn, 21 Jan 1995 (holo: NSW; iso: BRI, HO, MEL, NE).

$\dagger$ Deceased 31 July 2005

(C) 2007 Royal Botanic Gardens and Domain Trust 
Much-branched shrub to 2-10 m tall; branchlets fawn to grey, shortly pubescent to scabrous or very rarely glabrescent with age. Leaves alternate, spread along stems; narrowly ovate, narrow-elliptic to broadly ovate, slightly asymmetric; $1.05-5 \mathrm{~cm}$ long, $0.4-2.6 \mathrm{~cm}$ wide; veins 7 , at least 5 usually easily visible though sometimes obscure especially adaxially; margins distinctly thickened, slightly recurved; base broadly tapering; acute; tip usually obtuse (due to apex dying), sometimes abruptly so, or rarely acute, always dry, brown and brittle; usually glabrous except for scabrous hairs restricted to the edges or more rarely minutely scabrous to sparsely pustulate adaxially; margins minutely fimbriate to minutely ciliate, usually restricted or more prominent in the distal third but sometimes along the whole margin; glossy deep green above, paler abaxially, new growth red. Petiole $1.5-4.5 \mathrm{~mm}$ long; shortly pubescent, rarely hairs restricted to adaxial groove. Caducous early season growth bracts to $4.2 \mathrm{~mm}$ long, marginally ciliate, pubescent abaxially on distal half. Inflorescences terminal and axillary racemes of c. 20 flowers. Pedicels $0.2-0.5 \mathrm{~mm}$ long. Bracts $1.1-1.6 \mathrm{~mm}$ long, $1-1.1 \mathrm{~mm}$ wide, sometimes keeled, margins ciliate, pubescent abaxially on distal half. Bracteoles 1-1.1 mm long, ovate to elliptic, margins ciliate, sometimes keeled and pubescent abaxially on the distal half. Calyx 1.2-2 mm long, 0.6-1.1 mm wide; ovate to elliptic; margins ciliate, pubescent abaxially on the distal half. Petals 2.8-3.5 mm long; tube broader above, 1.6-2.1 mm long, 1.4-2.1 mm wide at the mouth; lobes erect to spreading, 1.2-1.6 mm long, 1-1.3 mm wide; lobes and top half of the tube adaxially densely hairy, hairs spreading on lobes and reflexed in tube, hairs $0.3-1 \mathrm{~mm}$ long, margins papillate. Anthers dorsally apically connected to the filaments, $0.7-1.1 \mathrm{~mm}$ long; filaments $0.6-0.8 \mathrm{~mm}$ long. Ovary $0.7-0.9 \mathrm{~mm}$ long; $0.7-0.9 \mathrm{~mm}$ wide; disc prominently toothed to undulate, $0.4-0.6 \mathrm{~mm}$ high. Style $0.4-0.7 \mathrm{~mm}$ long, with a broad base. Fruit $4.5-6 \mathrm{~mm}$ wide, 7-11 locular, purple to black, depressed globose; seed 2.5-3.5 mm long, 1.5-2.5 mm wide. Flowering mainly late September to October.

Additional specimens examined: New South Wales: Northern Tablelands: Point Lookout, McCusker, 17 Dec 1956; Point Lookout, Tayles, 16 Mar 1958; Point Lookout, NENP, Hore-Lacy, 12 Feb 1963; Point Lookout, Wissmann, Oct 1989; Track to Wrights Lookout, New England National Park, Telford 12669 \& Bruhl, 11 Dec 2003; 14 km east of Ebor, 7 km along Dawsons Rd, Needham, 14 Mar 1999; Tom's Cabin, New England NP, Williams, Jun 1976; Tom's Cabin, Point Lookout, Sawyer, 28 Sep 1989; Softwood Rd, Styx River Forest Way, Styx River SF, Williams, 22 Apr 1978; Snowy Creek, Ebor, Wissmann, 26 Oct 1969; Slopes SE of Cathedral Rock, near Ebor, Smith 20, 25 Sep 1974; Cathedral Rock NP, near Ebor, SE of Cathedral Rock, Smith 187, 21 Mar 1975; Mt Hyland NR, Williams, 30 Oct 1985; Cobark, Gloucester to Barrington Tops Road, Griffith, 15 Jul 1982; Barrington Tops, west of Gloucester, Williams, 12 Jul 1983; Plateau Beech Reserve, Werrikimbe NP (N of Yarras), Bale, May 1989; Werrikimbe, upper Forbes River, Bale, Jun 1989; Site 14, Ngulin NR flora survey, Hunter, 9 Sep 2005; Site 16, Ngulin NR flora survey, Hunter, 9 Sep 2005. (All NE).

Distribution: the known populations are all restricted to altitudes above $1000 \mathrm{~m}$ in seven general locations; the Styx River area, New England and Cathedral Rock National Parks and Mt Hyland Nature Reserve around Ebor and Werrikimbe National Park (Walcha), Nbulan Nature Reserve (Nowendoc) and the Barrington Tops area (Fig. 1).

Habitat: commonly found in and on the margins of Nothofagus moorei cool temperate rainforest and warm temperate rainforest but also in tall wet eucalypt forests dominated by Eucalytpus obliqua (Floyd 1989; Clarke et al. 2000; Hunter 2005; Harden et al. 2006); at altitudes between 1000 and $1600 \mathrm{~m}$. The species has been found on a variety of rock types from basalt, acid volcanics, phyllites and granite with soils that are usually clay loams. 
Notes: this species is closest to Trochocarpa laurina (Rudge) R.Br. in overall features but differs in the combination of a number of characters (Table 1). Most notable is the smaller size of many features, particularly the leaves and fruits. In addition T. montana is hairy on the branchlets, petioles, leaf margins (sometimes adaxial leaf surface) and on the abaxial surface of bracts, bracteoles and sepals, whereas T. laurina is glabrous on these parts. The phyllotaxy is also different, being distinctly alternate in T. montana and pseudo-whorled in T. laurina; overall leaf shape is different, with T. montana being usually broadest below the middle, (similar to T. bellendenkerrensis Domin), whereas T. laurina is broadest at the middle. Small-leaved forms of T. laurina have been found near Dorrigo and Tenterfield in New South Wales and the Lamington area of south-east Queensland which superficially resemble T. montana solely due to foliage size. These small-leaved T. laurina do not possess any of the other diagnostic features of T. montana (Table 1). Specimens of T. montana from the Walcha, Nowendoc and Barrington Tops areas differ from the type form in having larger and broader leaves and a generally more dense and longer indumentum on most parts.

Table 1. Diagnostic characters separating Trochocarpa montana from T. laurina.

\begin{tabular}{|c|c|c|}
\hline Feature & T. montana & T. laurina \\
\hline Stems & $\begin{array}{l}\text { densely to sparsely } \\
\text { shortly pubescent, } \\
\text { rounded to angular, grey } \\
\text { to fawn }\end{array}$ & $\begin{array}{l}\text { glabrous } \\
\text { angular, } \\
\text { grey to black }\end{array}$ \\
\hline Petiole length (mm) & $1.5-3.5$ & $3-7$ \\
\hline New leaves & bright red & pale green to pink \\
\hline Leaf length (cm) & $1-5$ & $5-9$ \\
\hline Leaf width (cm) & $0.4-2.6$ & $1.5-4.5$ \\
\hline Leaf margins & minutely fimbriate & smooth \\
\hline Leaf arrangement & $\begin{array}{l}\text { alternate } \\
\text { spread along stems }\end{array}$ & $\begin{array}{l}\text { pseudo-whorls } \\
\text { sometimes alternate, } \\
\text { often clustered } \\
\text { below buds }\end{array}$ \\
\hline Leaf apex & $\begin{array}{l}\text { obtuse rarely acute, never } \\
\text { acuminate }\end{array}$ & acute to acuminate \\
\hline Leaves & $\begin{array}{l}\text { usually widest below } \\
\text { the middle, } \\
\text { narrowly ovate or } \\
\text { rarely elliptic }\end{array}$ & $\begin{array}{l}\text { widest at the middle, } \\
\text { elliptic to } \\
\text { broadly elliptic. }\end{array}$ \\
\hline Corolla lobes & $\begin{array}{l}\text { erect to spreading, } \\
\text { white }\end{array}$ & recurved, cream \\
\hline Nectary & $\begin{array}{l}\text { prominently toothed } \\
\text { (usually 2-toothed) }\end{array}$ & $\begin{array}{l}\text { truncate to rounded or } \\
\text { shallowly 3-4 toothed }\end{array}$ \\
\hline Bracts and sepals & $\begin{array}{l}\text { margins ciliate, } \\
\text { dorsal keel indumented }\end{array}$ & $\begin{array}{l}\text { margins ciliate } \\
\text { otherwise glabrous }\end{array}$ \\
\hline Fruit colour & purple to black & $\begin{array}{l}\text { black to bright purple } \\
\text { or yellowish }\end{array}$ \\
\hline Fruit width (mm) & $4-6$ & $6-8$ \\
\hline
\end{tabular}


Conservation status: Trochocarpa montana has a highly disjunct distribution, being restricted to the higher altitudes in very specific cool and moist environments. The species is known from only seven general locations, and though common at these sites, this taxon is highly susceptible to climate change and changes in fire regimes, both of which are listed as key threatening processes in the New South Wales Threatened Species Conservation Act 1995 (TSC 1995, 2002, 2004). Thus it is suggested that T. montana should be considered vulnerable and listed as such (TSC 1995, 2002, 2004; EPBC 1999).

Etymology: the epithet montana refers to the occurrence of all populations at high elevations; it was a manuscript name written on preliminary diagnostic notes on this taxon made by the senior author since 1967. Known colloquially as Mountain Tree-heath.

\section{Acknowledgments}

Thanks to Dr Jeremy Bruhl for facilitating access to the N.C.W. Beadle Herbarium at Botany in the University of New England, Armidale. Peter Wilson assisted with the latin diagnosis.

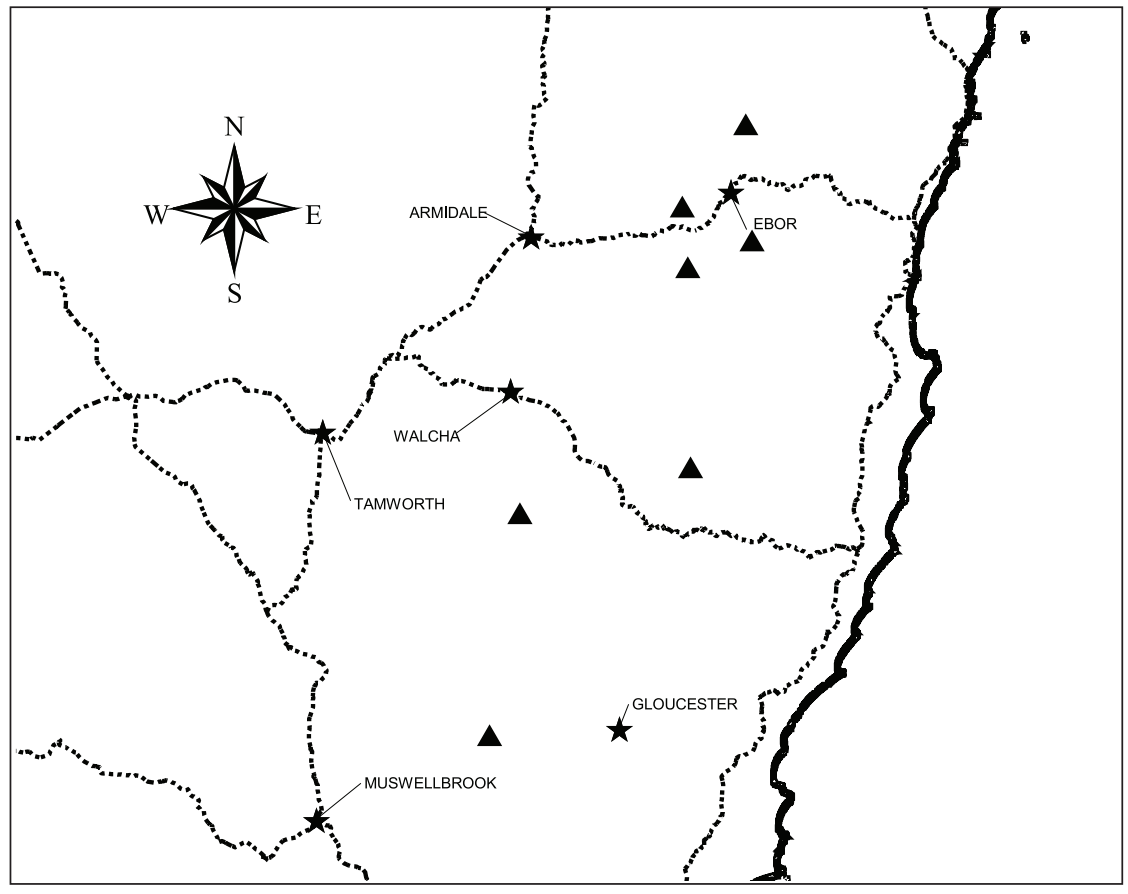

Fig. 1. General distribution map of Trochocarpa montana (triangles) in northern New South Wales. ---- Major Roads _ Coastline $\star$ Towns 


\section{References}

Clarke PJ, Copeland LM, Noble NE, Bale CL \& Williams JB (2000) The vegetation and plant species of New England National Park. (Botany, University of New England: Armidale)

EPBC (1999) Environment Protection and Biodiversity Conservation Act 1999 (http://www.deh. gov.au/epbc/index.html)

Floyd AG (1989) Rainforest trees of mainland South-eastern Australia. (Inkata Press: Sydney)

Harden G, McDonald B \& Williams JB (2006) Rainforest trees and shrubs: a field guide to their identification. (Gwen Harden Publishing: Nambucca Heads)

Hunter JT, Williams JB \& Conn BJ (2006) Rediscovery of Prostanthera staurophylla F.Muell. and reinstatement of $P$. teretifolia Maiden \& Betche (Lamiaceae). Telopea 11: 117-126.

Hunter JT (2002) Vegetation and floristics of Ngulin Nature Reserve. Report to the New England Region of the New South Wales, National Parks and Wildlife service.

Quinn CJ, Crayn DM, Heslewood MM, Brown EA \& Gadek PA (2003) A molecular estimate of the phylogeny of Styphelieae (Ericaceae). Australian Systematic Botany 16: 581-594.

TSC (1995) Threatened Species Conservation Act 1995 No 101, in 'In Force Legislation' (http://www.legislation.nsw.gov.au/maintop/search/inforce).

TSC (2002) Threatened Species Conservation Amendment Act 1995 No 78. in 'In Force Legislation' (http://www.legislation.nsw.gov.au/maintop/search/inforce).

TSC (2004) Threatened Species Conservation Amendment Act 1995 No 88. in 'In Force Legislation' (http://www.legislation.nsw.gov.au/maintop/search/inforce).

Wiecek B (1992) Trochocarpa. Pp. 433-434 in Harden GJ (ed.) Flora of New South Wales, vol. 3. (New South Wales University Press: Kensington)

Williams JB \& Hunter JT (2006) Boronia boliviensis (Rutaceae series Erianthae), a new rare granite outcrop endemic from north-eastern New South Wales. Telopea 11: 260-264.

Williams JB, Harden GJ \& McDonald WJF (1984) Trees and shrubs in rainforests of New South Wales and southern Queensland. (University of New England: Armidale)

Manuscript received 28 September 2006, accepted 06 March 2007 